ISSN: 2639-359X

Volume 1, Issue 2, 2018, PP: 23-32

\title{
Understanding the Human Aging Body - A Critical Exegesis
}

\author{
Jason L. Powell \\ University of Chester, UK. \\ j.powell@chester.ac.uk
}

*Corresponding Author: Prof. Jason Powell, PhD, FHEA, FRSPH, FRSA, Department of Social and Political Science, Westminster Building, The University of Chester, Parkgate Road, Chester, CH1 4BJ, UK.

\section{Abstract}

This article critically engages with the importance of the aging body as applied to understanding both the praxis of aging studies. We begin our journey by looking at the disciplinary dominance of bio-medical models in understanding bodily change through later life. The paper then movesits analysis to the relative absence of theoretical models within aging studies that have attempted to analyse social explanations of the body. The paper critically questions the notion of the aging body and attempts to link its understanding to authentic epistemological insights deriving from wider contemporary social theory.

Keywords: Aging, Human Body, Bio-medicine, theory, social explanatory models

\section{INTRODUCTION}

Theoretical Narratives relating to the aging body in social gerontology are slowly developing (Powell, 2018). Whilst the 'body' as a concept implies an objectified and 'natural' entity, the body is now beginning to be viewed as increasingly complex. We all inhibit a specific, gendered, human body. The body, at once, is our means of freedom and location of our enslavement (Bordo, 1990; Butler, 1993). Chris Shilling (1993) claims it has made only a recent impact in social science disciplines in general. In the past few years, however, the epistemological work of Powell (2018), Featherstone and Hepworth (1993) and Katz (1996) have all put the idea of the body at the forefront of analysing social aspects of gerontology. Indeed, the importance of the body to gerontology is in many ways obvious. For example, the body in pain; illness, can limit functions of the body and this can have effects which stimulates the interest of social gerontologists of all backgrounds globally. David Morris posits in his engaging study, 'The Culture of Pain:

'Pain not only hurts but more often than not frustrates, baffles, and resists us. Yet it seems we cannot simply suffer pain but most always are compelled to make sense of it' (Morris, 1991: 18).
Moreover, the problem of making sense of "pain" and the reason why the body is central to the discipline of gerontology is that the bio-medical model in particular has devised the means to foster intellectual respectability to "scientific" ideas concerning aging that practically impinge upon altering the boundaries of the physical body (Freund, 1988). For example, it can reconstruct bodies through plastic surgery. Further, it can interfere with genetic structures; and it can swap internal organs from one human body to another (Bordo, 1993; Haraway 1991; Powell and Longino, 2001). "We", according to Haraway (1991), have become 'cyborgs' - not wholly machines and not wholly natural organisms either. She argues:

'Twentieth century machines have made thoroughly ambiguous the difference between natural and artificial, mind and body, self-developing and externally designed, and many other distinctions that used to apply to organisms and machines (Haraway, 1991: 10).

However, the literature as Shilling (1993) argues, infers a general ambivalence about the body: the more we know about bodies, and the more we are able to control, intervene, and restructure them, the more uncertain we become as to what the body actually is (Wahidin, 2002a). The boundaries between the 
physical body and society are becoming increasingly bifurcated. In this respect, in the multi-disciplinary field of gerontology, the body represents an important and significant area of study (Powell, 2018).

Nevertheless, the medical model has dominated the perceptions of old age. As Powell and Longino (2002) have pointed out, the medicalisation of old age is not an objective scientific process, but rather a series of struggles at local, national and international levels of policy. These struggles to define the nature of aging and the place of medicine within it, are between older and potentially old people, helping professionals of different types, entrepreneurs from family run care homes through to pharmaceutical companies of global reach and finally the institutions of the state and the organisation and distribution of resources through policy spaces (Biggs and Powell, 2001).

Hence, the dominant impact of medicalized notions of aging can also be seen in Moody's (1998) powerful critique of bioethics and aging and the cutting back of Obama's medicarecoverage in American welfare policy especially intensified under the controversialTrump administration (Powell, 2018). The bio-medical model has consistently problematized 'truths' about the decline element of adult aging in order to legitimize its power, control and disciplination of older people as subject of power and object of knowledge (Powell 2018). As Arthur Frank (1990, 135-6) notes, the biomedical model is dominant force in popular culture and and postmodern society:

'Medicine does ... occupy a paramount place among those institutions and practices by which the body is conceptualized, represented and responded to. At present our capacity to experience the body directly, or theorize it indirectly, is inextricably medicalized'.

According to Powell and Biggs (2000) the biomedical surveillance of older people has enabled the disciplinary and praxis process of bio-medicine to show 'benevolentconcern' for older people's 'declining' health and justifies acquiring scientific knowledge about their condition. Furthermore, according to Katz (1997), the effects of the decline analogy can be seen in the dominance of bio-medical solutions to the physiological 'problems' of aging bodies.

The somewhat hegemonic dominance of the biomedical model goes beyond negative discourses pertaining to aging, it has sought to re-invent itself as the 'saviour' of biological aging viathe bio-technological advancements that foster re-construction of the 'body' to prevent, hide or halt the aging process (Wahidin \& Powell, 2001). As Biggs and Powell, 2001 point out:

$\therefore$ established and emerging master narratives of biological decline on the one hand, and consumer agelessness on the other, co-exist, talking to different populations and promoting contradictory, yet interrelated, narratives by which to age. They are contradictory in their relation to notions of autonomy, independence and dependency on others, yet [they are] linked through the importance of techniques for maintenance, either via medicalized bodily control or through the adoption of "golden-age" lifestyles' (Biggs \& Powell, 2001, 97).

Because of the reluctance of socially trained gerontologists to deal directly with the body, and its tendency to hand the subject matter off to the physiologists and clinicians, the social study of age and the aging body has only gained theoretical momentum in the past twenty years on both sides of the Atlantic (Phillipson, 1998; Powell, 2018); Powell, 2001). Indeed, only in the past decade has there been any sustained attempt to fuse together theoretical concerns about aging bodies in order to foster a deeper understanding of aging identity (Featherstone and Wernick, 1995).

This article in particular examines the interconnection of two areas relevant to theoretical gerontology: aging body and wide social theory. The first area of the body is inter-connected to old age in that we provide critical questions as to what the body is and how it is linked to an understanding of old age in the popular imagination in western culture - here we trace the bio-medical dominance of ageing which impinges upon narratives afforded to understanding the body. Secondly, how we interpret and analyse old bodies is through the appropriation of wider social theory. We can engage with the philosophical insights deriving from wider contemporary social theory which provides a 'theoretical' tool for deconstructing dominant ideas and master narratives pertaining to an understanding of old age and body politics. It is by understanding the multi-faceted nature of the aging body that we can come to understand how the material constructs of the body constitute our relation with our bodies (Powell, 2018). 


\section{The Development of 'Aging Bodies'}

Where does the story of the human body begin? What, is in fact, meant by the 'body'? One can simply argue that the body is 'present', 'lived', 'real' and 'experienced'. The body in terms of its biology is always in the process of becoming. Cells die, mutate and regenerate. It can be argued from this proposition then, that the body never becomes but is left as an unfinished project, in a state of transition (Wahidin, 2002a).

The more we problematise the body the less sure we can be of what the body is and what the body represents (Powell, 2018; Featherstone 1991; Frank 1990, 1991; Wahidin \& Tate). The body in its material form has been taken for granted, absent or forgotten in gerontological literature (Featherstone, 1995; Oberg, 1996), until the body begins to mechanically break down. Thus the role of the body in gerontology has for some time focused on the failing body and the political response to the ageing body but not how typifications of old bodies intertwined with masculinity, femininity, sexual orientation and race serves to regulate and define the spaces that elders use (Powell, 2018).

Writing about body poses a series of challenges relating to the issue of human embodiment, the body and body-image (Featherstone and Hepworth, 1989). The body like parchment is written upon, inscribed by variables such as gender, age, sexual orientation and ethnicity and by a series of inscriptions, which are dependent on types of spaces and places. However, as Shilling (1993) argues, the more we know about (our) bodies the more we are able to govern, modify and que[e]ry gender norms highlighting how gendered and agist discourses serve to confine and define, old bodies.

Bryan Turner's (1995) emphasises several key processes, which work upon and within the body across time and space. This can be dependent upon the type of space, from the Benedictines religious time ordering to time, work and discipline and to the deployment of tansgressive or body-versive performativity (Wahidin, 2003). It can be argued that the body in its corporeal existence is complex in its design and can neither be reduced to biology or to the dictates of capitalism (Giddens, 1981). The role of the body in gerontological literature is central to understanding how the body becomes 'educated', constituted within a given time, space ordering, and regimes of femininity, masculinity and agist discourses. In other words, the body has to be contexualised within its polymorphous state of positions within and between a number of different discourses: the biological and the social, the collective and the individual; that of structure and agency.

Foucault (1973) has argued persuasively that the birth of the medical profession brought with it a different way of seeing illness and well-being related to structural and personal spaces. Most notably, the sick other became an object to be modified (Powell and Biggs, 2000). Under the 'medical gaze', people become their bodies, bodies disaggregated into a series of dysfunctional parts. This is useful for the scientific analysis of function and remedy but severely limits any perspective that takes into account interpersonal and wider social factors (Powell, 2018).

Longino and Powell (2003) give as an example, here, how cracking the genetic code of biological ageing has directed attention away from socially determined lifechances in later life. Power relations become eclipsed by narratives of technological application by a skilled professional subject to manipulation and control. This is often a concern of medical students as they begin their education, but is also often lost as part of their induction into a bio-medical culture (Longino and Powell, 2003).

Powell and Longino (2002) have argued that the disaggregation of the aging body takes a number of forms. First, the experience of aging is broken down into a number of separate age categories each with its accompanying medical specialism. Second, that the dominance of bio-medical perspectives on ageing has lead to an acceptance of the association between adult aging and bodily and mental deterioration (Moody, 1998). Finally they note that a combination of specialism and a separation of mind from the body, has compromised the gendered experience of bodily ageing (Powell and Longino, 2002). If aging becomes associated with illness, and the avoidance of aging with cure, then an expansion of medical discourse to include ever more aspects of the older person's lifeworld leaves two alternatives: subsumption of the self under the rubric of a sick body or a continual flight from the 'symptoms' of aging (Longing and Powell, 2003). Both depend upon bio-medical hegemony (Biggs and Powell, 2001). It follows from the above analysis that a bio-medical approach to aging encourages the evacuation of certain forms of experience, through the re-classification of experience into symptoms which 
can then be addressed separately from wider social impacts (Phillipson, 1998).

Frank (1998) argues that the ability to tell ones own story of illness is by no means straight-forward. If as Foucault (1976) claims, the maintenance of existing power relations depends not on the use of force, but on the ability to persuade active subjects to reproduce those relations for themselves, then the telling of narratives will always be suspect. Further, Frank (1998) poses the almost unanswerable question of when does self-care turn into a technology for producing a certain sort of self ? Personal narratives, particularly for older people in health settings, remain both a means of taking care of oneself and conformity to a restricted legitimising discourse of their bodies.

\section{TOWARDS A NEW THEORY OF THE AgING Body}

It is by querying the role of the body that one can move away from the bio-medical approach, which locate the body within the naturalistic framework (Frank, 1990; Biggs and Phillipson, 1998; Powell, 2018). The social constructivist perspective, adds a richness to the literature by examining embodiment and the corporeality of the body in all it social guises (Wahidin and Powell, 2001). It places the body not as a passive materiality that is acted upon but one, which negotiates the capillaries of power enabling the body to be always in the process of becoming through the experiences of embodiment (Laws, 1995). This perspective moves away from a purely professional discourses and centres the role of the body as 'real', 'lived' and 'experienced'. For example, the phenomenological perspective of MerleauPonty (1996), should be seen as an effect of a broader concern with the understanding of everyday life. Moreover, in a post modern culture, the prospect of an endless life has been revived through consumer images of perpetual youth and the blurring of traditional life course boundaries (Featherstone and Hepworth, 1991).

The body is thus a contested site within which gender norms, age related expectations and the disciplinary nature of society operates a nexus of binary oppositions. It is by drawing the role of the body that one can move away from the perspectives, which locate the body within the naturalistic and the social constructionist framework (Frank, 1990, Wahidin 2002; Powell, 2018). For example, it can be argued that women body builders, women who have eating disorders or women who self mutilate are resisting normalised forms of hegemonic femininity by reinscribing and transgressing the limits of their body.

The body project - bodybuilding, dieting, involve the celebration of the ideal physique rather than the techniques involved in subverting hegemonic norms of femininity. The role of the body has become a discursive site of power to be produced, acted upon and received (Powell, 2018). These techniques create the space for resistance enabling power to be positive and at the same time negative. Sandra Bartkly, for instance has argued that:

'normative femininity is coming more and more to be centred on woman's body - not its duties and obligations or even its capacity to bear children, but, but its sexuality, more precisely its presumed heterosexuality and its appearance' (Bartky, 1988:83).

For Bartky, practices such as 'pumping iron', controlling bodily weight may thus been seen as an example of the 'experimentation with new styles of the flesh' (ibid:83) that is needed in order to resist 'conventional standards of feminine body display' (ibid: 78).

It can be argued that women body builders, elders with eating disorders might also be said to be resisting normalised forms of hegemonic femininity by reinscribing the body. In this way, such activities could be said to differ from other forms of the body project - dieting, keep fit which involves the celebration of the ideal type rather the denigration / revulsion of hegemonic norms of femininity (Wahidin and Tate, 2003). Old bodies self governed by regimes of exercise become the object of their own gaze, in order to maintain their commitment to training or the self imposed non-eating regime to achieving a particular body project. The inscription is partially in opposition to the category woman, thus disrupting the gaze of the other. In becoming the object of their own gaze they become powerful in being invisible as the source of the gaze (that is, the one who looking without being looked at) ( Tseelon, 1995:68; Powell, 2018)

One cannot argue in relation to body modification that the performance of the body is solely one to counter / resist/ subvert hegemonic discourse. Or one phased purely on aesthetic value without fully encapsulating the multi varied / faceted technologies of corporeal and self. Through these bodily practices old bodies are transforming their gendered habitus and thus 
creating identities for themselves which transgress the boundaries of how to manage old bodies (Wahidin 2003).

Throughout particular literary texts (Greenblatt, 1980) and through representations of the celebrated youthful body; the old body is something to be feared and resisted and thus at all costs should be held at bay. The ultimate penality of ageing for many of the elders is when in the mechanical sense the body begins to break down. Infantilised not by the system or techniques of punishment in place but by their own bodies (Powell, 2018).

'Degrees of loss impair the capacity to be counted as a competent adult. Indeed, the failure of bodily controls can point to a more general loss of self image; to be ascribed the status of a competent adult person depends upon the capacity to control urine and feces. (Featherstone and Hepworth 1991: 376)

The dislocation felt between their eternality of the body or the surfaces of the body that symbolise the self at a time when youthfulness is valued to a internality of body leaves many to combat age through 'maintaining' their bodies via the commodification of youth. Appearance, social acceptability argues Featherstone $(1991 ; 186)$ becomes central to a person's social acceptability .

The performance of the body is indicative of how the body is a discursive site of power to be produced, acted upon, negotiated and received. These techniques create the space for resistance enabling power to be positive yet at the same time negative. It is the polysemic nature of the body in all its guises that the performance is not solely one to counter / resist / subvert hegemonic prison discourse. It is rather a relationship encapsulating the multi-varied technologies of corporeal and self inscriptions based on what went on before, the present and immediate past (Powell, 2018).

There are obvious tension between the commodification of old age and being laid out to pasture. It is through constructing and transgressing images old bodies, by subverting the 'stigma' surrounding later life (Goffman, 1984), and thus redefining physical capital (Bourdieu, 1978) that many old bodies resisted the images of old age. Moreover within this discursive space the construction of the ageing body (Tseelon, 1995), allows elders to become their own significant other, to challenge the gaze of others and to "be for themselves'. Their bodies, therefore, become sites of empowerment whether they collude or resist ageist stereotypes (Powell, 2018). Furthermore, 'Power over their bodies' and 'power within their bodies' creates spaces in which they gain control.

Through these modalities of power, these bodily practices are in effect transforms their gendered habitus and in turn creating identities and spaces which transgress the boundaries of what it is to be an old body in an hetro-young and able bodied conscious world.

In a post-modern culture, the prospect of an endless life has been revived through consumer images of perpetual youth and a blurring of traditional life course boundaries (Featherstone \& Hepworth, 1991) Bauman, (1992) says of the 'postmodern strategy of survival', compared to 'traditional ways of dabbling with timelessness,' that,

'instead of trying (in vain) to colonize the future, it dissolve it in the present. It does not allow the finality of time to worry the living ....by oscillating time (all of it, exhaustively, without residue) into short lived , evanescent episodes. It rehearses mortality, so to speak, by practicing it day by day (Powell, 2018; Bauman, 1992:29).

Foucault's account of the relationship between governance and disciplinary society is important in understanding how discourses and subjugation pervade all areas of life, 'with the aim of producing and shaping an obedient subject' (Foucault, 1977:33). Foucault uncovers the ways in which knowledge and power are constituted in each other, and especially in the ways in which this mutual interdependence effectively exercises discursive practices of social control:

Power and knowledge directly imply each other.... there is no power relation without the correlative constitution of a field of knowledge, nor any knowledge that does not presuppose and constitute at the same time power relations' (Foucault, 1977: 27)

Technologies of disciplinary power are inseminated in the process of regulating, and manufacturing a type of human behaviour which in turn accelerates the ageing process by rendering invisible the needs, experiences and voices of persons in later life (Rose, 1996; Wahidin 2004). The gendered body is a discursive site in which 
power is produced, acted upon, engaged with and received. These aspects of power allow spaces for resistance to emerge, enabling power to be positive and at the same time negative. The experiences and knowledge of life before in the celebrated youth body, the life threads of familial responsibilities, motherhood, fatherhood, youth, inscribes the body's experiences which in turn enables or disables the success of performance of survival on the aging platform (Powell, 2018).

Central to this discussion is how the inscription of age, femininity, masculinity, ethnicity, class and sexual orientation are placed on and works in tandem with the rhythms of the body. The body is constantly operating within fields of temporality, in which mobile networks of relations produce and transmit power/knowledge to the object vis a vis subject (Butler 2000). Thus the body operates within fields of power and within realm of signs. It has been argued that time and identity in society consist of a multiplicity of discursive elements that come into play at various times, whereby existing in 'different and even contradictory discourses (Foucault, 1982: 100-2). The Foucauldian lens allows an analysis that goes beyond domination and subornation and truth or deception or them and us. It has been argued throughout that aging body is a resource, which can be managed in a number of ways in order to construct. For example, the body can counter/resist/subvert hegemonic penal and ageist discourse without fully encapsulating the multivaried/multi-faceted technologies of corporeality and self. The body is a 'visage' a collection of signs to be interpreted. It becomes a façade (cf. Goffman 1983), which at the same time both conceals and expresses the inner being. It is by centralising the historical development of the body in gerontological theory that one can illustrate and interrogate how the architecture of the agist discourse re-codes their now 'profaned' bodies. The effects of constructing some bodies as marginal, other in turn are bodies which become excluded from mainstream representations defines boundaries and gives the rest of society its legitimacy to claims of what is a 'natural', 'normal' and 'rightful' bodily look (Powell 2018)

In order to survive the youthful prism, elders create strategies of subversion. They transgress spacetime walls by bringing into play, a masking motif. The mask motif is used by women and men in later life to examine the relationship between the social world and themselves and the expectations placed by the social system upon them (Powell, 2018). The inscriptions placed upon the body and the performing outward mask formed under the gaze by elders in order to 'make do', is one that enables elders to counter/resist and subvert hegemonic age-normative discourse. Furthermore, encapsulating the multivaried technologies of corporeal and self inscriptions.

Identity management is vital in order to survive a culture which forces elders to disengage by providing a means to recede from the gaze (Biggs, 1997) This tacit knowledge recreate elders as knowing agents within a system which attempts to suppress the sense of self by recreating meaning with the aim to 'produc[e] and shap[e] an obedient subject' (Foucault, 1977:5).

As one ages, society inscribes an invisible code similar to the body idiom described by Goffman (1963; the body resists, negotiates and is a receptor, generator and interpreter of the social meanings produced externally and internally by elders. Old bodies respond to the writing on the body by utilizing a masking insignia. The mask motif mediates the relationship between the appearance and the essence, not to separate identities but one in which the governance of identity boundaries blur, separating, and creating new possibilities for the body to transgress (Powell, 2018). It can be argued that the body becomes a resource, which can be managed in a variety of ways in order to construct and protect a version of the self. The mask becomes a shield not only from the intrusive glare of medico discursiveness, but a survival strategy, a coping mechanism to survive a turbulent and violent environment. One can argue that the mask is an extenuation of refracted selves an outward facing mask that creates a sartorial face (Powell, 2018). The outward mask manifests itself in a multi-variable way. The body is a malleable receptacle that is acted upon, receives but also produces mechanisms, which aim to reinforce, preserve and protect elders even in the most extreme conditions. The performance is a process of negotiation, which clearly illustrates how elders can regain control. This performance becomes a series of tactical game like moves to ensure survival. It becomes an end in itself and a means to an end. We want to emphasize that the outward mask does 'not necessarily imply a deep and abiding identification with that appearance' (Goffman 1983:51). The mask motif enables elders in prison the ability to 'stand outside themselves looking at their own creations, 
knowing that they are real, but knowing also that they have made them' (Edgley and Turner 1975:6). The 'practices of the self ' (Rose 1990) are used to negotiate the change in environment and preservation of their relational but sartorial faces (i.e: the mask is not the same as being false, manipulative or deceptive). It is through the sartorial body which create networks between how elders are constructed by the young and able bodied and finally how they affirm continuities with the self and their life before (Powell, 2018). Yet at the same time they are aware that through active disengagement, they are re-configuring how they present their needs in system where their voices are often unheard (Powell, 2018; Wahidin, 2002b; 2003; Wahidin and Tate 2003).

As argued above the body is a dynamic, nebulous in form and is always in the process of becoming (Powell, 2018). The contours of the body outline a visible but transitional object (Featherstone and Wernick, 1995). But as Butler (2000) argues there is no surety of what the body is. What one can argue from discussion of the body, is that it becomes the threshold through which the subject's lived experience of the world is incorporated and interpolated and, as such can never be purely understood. The body is in situe, placed within various temporal and spacial fields of power. In Elizabeth Grosz's words (1994), the old body is a 'transitional entity'; power is produced, generated and negotiated in terms of the inscriptions placed on the aging body.

The application of Foucault's work brings a richness to networks of power and the use of Butler's concept of 'performativity' in relation to the composite role and configuration of the body seeks to show that the internal essence of gender is manufactured through a sustained set of acts, positioned through the gender stylisation of the body (Wahidin, 2003). In this way, it shows that what we take to be an 'internal' feature of ourselves is one that we anticipate and is produce through and by certain bodily acts (Powell, 2018).

We have argued that old bodies through the iterability of performativity which is a theory of agency, that one cannot disavow power as the condition of creating its own possibility (Powell, 2018). Bodies young, old and ageing/ developing are posited in a series of conflicting discourses and networks of power. In living through time the body in its materiality, becomes almost a medium, on which power operates and through which it functions. What we have aimed to do is to illustrate that the body is neither brute nor passive, static in being but is interwoven with and constitute of systems of meaning, signification and representation that the elders through the performativity of the body negotiate the gaze (Powell, 2018).

\section{Concluding Comments}

This paper has critically engaged with the dominant discourses deriving from bio-medical approach to the body. The paper then moved our attention to drawing from insights from wider social theory which provides compelling questions of how we interpret, problematize and understand the body as subject (Powell, 2018). Hence, the paper has demonstrated how the body is not separate from the body subject (MerleauPonty, 1996) but is intertwined. Frank (1991) argues that simultaneously, the embodied agent becomes both a producer of society whilst at the same time; it is society, which creates the embodied agent. Old bodies are not passive objects but find ways of governing the capillaries of space, ageist discourses through the performativity of the aging body by evoking the masquerade (Biggs, 1999; Powell, 2018). Butler argues (1987), 'that gender is not written on the body as the torturing instrument of writing in Kafka's 'In the Penal Colony'; inscribing itself unintelligibly on the flesh of the accused. The question is not: what meaning does that inscription carry within it, but what cultural apparatus arranges this meeting between instrument and body, what interventions into this ritualistic repetition are possible?' (1987:186). It is by re-imagining the boundaries of the body that we can to begin to understand how the gaze, 'inscribes itself unintelligibly on the flesh of the accused'. This can be done through looking at both the meanings of its inscription for old bodies and the disruptive agentic repetitions in the daily practices in which old bodies engage (Powell, 2018).

The argument present here, demonstrates an understanding of the body as both 'real', lived through and as constructed. The study of the body in gerontological literature needs to engage with the real materiality of bodies and at the same time understand the ways in which bodies are performed, represented and positioned (Powell, 2018).

The re-territorialization of the aging body by society, and paradigmatically by social gerontology, is a strategy that parallels the denial of subjectivity within 
the main traditions of the biomedical model (Powell, 2018).

\section{REFERENCES}

[1] Bauman, Z. (1992), Intimations of Post Modernity. London: Routledge.

[2] Berthelot, J. (1986), Sociological Discourse and The Body in Theory Culture and Society 3, 155164.

[3] Biggs, S. (1993). Understanding Ageing. Milton Keynes: OUP.

[4] Biggs, S. (1996). A family concern: elder abuse in British social policy. Critical Social Policy. 16.2:63-88.

[5] Biggs, S. (1997), Choosing Not To Be Old? Masks, Bodies and Identity Management in Later Life in Ageing in Society 17:553 - 570.

[6] Biggs, S. (1999). The Mature Imagination. Milton Keynes: OUP.

[7] Biggs, S and Powell, J.L (2001) A Foucauldian Analysis of Old Age and the Power of Social Welfare in Journal of Aging \& Social Policy Vol.12, (2), 93-111

[8] Bordo, S. (1993), Unbearable Weight: Feminism, Western Culture and the Body, Berkeley, University of California Press.

[9] Bourdieu, P. (1978), Sport and Social Class, in Social Science Information 17 (6): 819-40.

[10] Butler, J. (1987), Bodies that Matter on the Discursive Limits of 'Sex', Oxford: Clarendon.

[11] Falk, P. (1994), The Consuming Body, London: Sage.

[12] Falk, P. (1995), Written in The Flesh, in Body and Society 1 (1), 95-105.

[13] Featherstone, M. (1982), The Body in Consumer Culture in Theory, Culture and Society, 1:18-33.

[14] Featherstone, M. (1991), Consumer Culture and Postmodernism: London, Sage.

[15] Featherstone, M. (1995), Post-Bodies, Ageing and Virtual Reality in $M$, Featherstone, M and A. Wernick, Images of Aging - Cultural Representations of Later Life: London, Routledge.
[16] Featherstone, M. and Hepworth, M. (1991), The Mask of Ageing and the Postmodern Lifecourse in M Featherstone, M Hepworth, B Turner, (eds), The Body, Social Process and Cultural Theory: London, Sage.

[17] Featherstone, M. and Hepworth, M. (1993), Images of Ageing in J. Bond, P, Coleman, and S, Peace (eds), (1993), Ageing in Society - An Introduction To Social Gerontology, London, Sage.

[18] Featherstone, M. and Wernick. A (1995), Images of Aging - Cultural Representations of Later Life, London, Routledge.

[19] Featherstone, M.and. Hepworth M. (1989), Ageing and Old Age: Reflections on the Postmodern Life Course in B. Bytheway; T. Keil, K. Teresa, P.Allatt, and A. Bryman,(eds), Becoming and Being Old Sociological Approaches to Later Life: London, Sage.

[20] Foucault, M (1982), The Subject and Power in Critical Inquiry Vol 8: 777-79.5

[21] Foucault, M. (1976), The Birth Of The Clinic An Archaeology of Medical Perception London, Routledge: Tavistock.

[22] Foucault, M. (1977), History of Sexuality Vol. 1. London: Penguin.

[23] Frank, A. (1990), Review Article-Bringing Bodies Back in A Decade Review in Theory, Culture and Society Vol 7, 131-162.

[24] Frank, A. (1991), For a Sociology of the Body: An Analytical Review in M Featherstone, M. Hepworth and B. Turner (eds), The Body Social Processes and Cultural Theory: London: Sage.

[25] Frank, A.W. (1996). The Wounded Storyteller: Body, Illness and Ethics, Chicago: University of Chicago Press.

[26] Frank, A.W. (1998). 'Stories of illness as care of the self: a Foucauldian Dialogue', Health, 2, 3, 329-348.

[27] Freund, P. (1988). 'Bringing society into the body: understanding socialized human nature', Theory and Society, 17: 839-64.

[28] Giddens, A. (1981), Agency, Institution and Time - Space Analysis in K. Knorr-Cetina and A.V. 
Understanding the Human Aging Body - A Critical Exegesis

Cicourel (eds),Advances in Social Theory and Methodology Toward an Integration of Micro and Macro Sociologies Boston Routledge and K.P:161-174.

[29] Goffman, E. (1963), Behaviour in Public PlacesNotes on the Social Organisation of Gatherings, New York Free Press.

[30] Goffman, E. (1983), The Interaction OrderThe American Sociological Association, 1982 Presidential Address in American Sociological Review - Official Journal of The American Sociological Association Feb 1983: Vol: 48 No 1.

[31] Grosz, E. (1994), Volatile Bodies: Towards a Corporeal Feminism, Bloomington, Indiana University Press.

[32] Haraway D. (1991), Siminas, Cyborgs and Women, London, Free Association Books.

[33] Katz, S. (1997). Disciplining Old Age: The Formation of Gerontological Knowledge. Charlottesville: UPV.

[34] Katz, S. (1999). 'Lifecourse, lifestyle and postmodern culture: corporate representations of later life, paper presented at Restructuring Work and the Lifecourse: An International Symposium, Institute of Human Development, University of Toronto.

[35] Laws, G. (1995). Embodiment and emplacement: identities, representation and landscape in Sun City retirement communities. International Journal of Aging \& Human Development. 40.4: 253-280.

[36] Longino, C.F and Powell, J.L (2003) 'Embodiment and the study of Aging' chapter in Berdayes, $\mathrm{V}$ (Ed.) The Body in Human Inquiry. The Hampton Press

[37] Morgan D (2002), The Body in Pain, In M. Evans \& E. Lee (ed) (2002) Real Bodies: A Sociological Introduction, London Palgrave.

[38] Morris, D. (1998), The Culture of Pain, Berkeley and Los Angeles: University of California Press.

[39] Moody, H. (1998). Aging, Concepts and Controversies. Thousand Oaks: Pie Forge Press.

[40] Oberg, P. (1996), The Absent Body - A Social
Erotological Paradox in Ageing and Society 16:701-719.

[41] Phillipson, C. (1998). Reconstructing Old Age. London: Sage.

[42] Phillipson, C. and Biggs, S. (1998). 'Modernity and Identity: themes and perspectives in the study of older adults, Journal of Aging and Identity, 3, 1, 11-23.

[43] Powell, J.L. and Biggs, S (2000). 'Managing Old Age: The Disciplinary Web of Power, Surveillance and Normalisation', Journal of Aging and Identity, 5, 1, 3-13.

[44] Powell, J.L and Longino, C.F (2002) 'Postmodernism V Modernism: Rethinking Theoretical Tensions in Social Gerontology', Journal of Aging \& Identity, 7, (4), 107-11

[45] Powell, J.L. (2018) Lifecourse and Society. New York: Nova Science

[46] Rose, N. (1996), Identity, Genealogy, History, in S. Hall and P. Gay, Questions of Cultural Identity, London: Sage. (Chp 8: 130-147).

[47] Shilling, C. (1993), The Body and Social Theory; London: Sage.

[48] Tseelon, E. (1995), The Masque of Femininity the Presentation of Women in Everyday Life, London, Sage.

[49] Tseelon, E. (1995), The Masque of Femininity the Presentation of Women in Everyday Life, London, Sage.

[50] Tulle-Winton, E. (1999). 'Growing old and resistance: towards a new cultural economy of old age?', Ageing and Society, 19, 281-299.

[51] Turner, B. (1989). 'Ageing, Status Politics and Sociological Theory' in British Journal of Sociology, 40: 588-606.

[52] Turner, B. (1995). Ageing and identity. In Featherstone, M. \&

[53] Wernick, A. (1995) Images of Ageing. London: Routledge.

[54] Wahidin, A and Powell J, (2001); The Loss of Aging and Identity: Social Theory, Old Age, and the Power of Special Hospitals in the Journal of Aging and Identity 6 (1):31-48, March 2001. 
Understanding the Human Aging Body - A Critical Exegesis

[55] Wahidin, A. (2002a). Living Life in the Shadows: A Qualitative Study of Older Women In Prison; Keele University, Unpublished PhD thesis.

[56] Wahidin, A. (2002b). Reconfiguring Older Bodies in the Prison Time Machine in the Journal of Aging and Identity 7 (3):177-193, September 2002.

[57] Wahidin, A. (20003), Managing ageing bodies in prison, chapter in E. Tulle (ed) 'Old Age and Human Agency'. Nova Science Publishers.

Citation: Jason L. Powell. Understanding the Human Aging Body - A Critical Exegesis. Open Journal of Geriatrics. 2018; 1(2): 23-32.

Copyright: (C) 2018 Jason L. Powell. This is an open access article distributed under the Creative Commons Attribution License, which permits unrestricted use, distribution, and reproduction in any medium, provided the original work is properly cited. 